\title{
The milk processing: Status, challenges and opportunities in ethiopia
}

\section{Mebrate Getabalew ${ }^{1}$, Tewodros Alemneh ${ }^{2 *}$ and Derbie Zewdie $^{1}$}

${ }^{1}$ College of Agricultural and Natural Resources Science, Department of Animal Science, Debre Berhan University, Ethiopia

${ }^{2}$ Woreta City Office of Agriculture and Environmental Protection, South Gondar Zone, Amhara Regional State, Ethiopia

Received: 20 January, 2020
Accepted: 28 May, 2020

Published: 29 May, 2020

*Corresponding author: Tewodros Alemneh, Woreta City Office of Agriculture and Environmental Protection, South Gondar Zone, Amhara Regional State, Ethiopia, Tel: 2519204998 20; E-mail: tedyshow@gmail.com Keywords: Livestock products; Milk export; Milk processing; Market channels; Dairy investment https://www.peertechz.com

\section{Check for updates}

\begin{abstract}
Livestock production in Ethiopia contributes about $16.5 \%$ of the national Gross Domestic Product (GDP), $35.6 \%$ of the agricultural GDP, $15 \%$ of export earnings, and $30 \%$ of agricultural employment. The performance of livestock product marketing was poor in the last decade, despite some improvement in recent years, especially in terms of aggressive policy and strategy on export of livestock and livestock products, indicating that the sector is still underexploited. There is need to promote the market-oriented production of milk export. Knowing the common challenges and opportunities are very much important in designing smart livestock and livestock product marketing systems in the country. The common milk processing products market constraints in Ethiopia include lack of clear milk marketing system, factors of culture and religion, inaccessibility of market and lack of transport, seasonal based demand, lack of effective extension service to use newer technologies and practices, lack of market information, lack of holistic intervention and localized markets. Despite these challenges, there are some golden opportunities that increase the milk demand and to some extent increase milk consumption trend. Hence, the need to review this work was to access literatures available regarding milk processing, status, challenges and opportunities in Ethiopia.
\end{abstract}

\section{Introduction}

Ethiopia is one of Sub-Saharan Africa's developing countries with a large potential in livestock, being first among African countries and $9^{\text {th }}$ in the world. However, milk production are very low [1]. The livestock production sub-sector has a huge contribution to the national economy and generating income to farmers, creating job opportunities, ensuring food security, providing services, contributing to asset, social, cultural and environmental values, and maintain livelihoods [2]. The subsector is mainly of smallholder farming system having multipurpose use and contributes about $16.5 \%$ of the national Gross Domestic Product (GDP), 35.6\% of the agricultural GDP, $15 \%$ of export earnings and $30 \%$ of agricultural employment [3].

There are some golden opportunities for milk processing; there is an increase in milk demand and to some extent consumption; capacities for improvement are available; new product development to increase customer selection (lifestyle products, probiotic yogurt, cottage cheese); distribution into multiple market channels to reach more consumers; institutional market segments (schools, hospitals); and improve packaging. There is political stability and conducive investment climate, government policy reforms, market orientation that are favorable for dairy investment. The cost of production for livestock products is generally low in the country. For milk production cost, Ethiopia is ranked among the countries with lowest cost of production in the world; the cost of labor is also low as compared to all the developed and many developing countries (personal communication) and Challenges of milk processing Insufficient raw milk supply for milk processing plants. This has forced the milk processing plants to operate with only $40 \%$ capacity and limited the production of pasteurized milk and other dairy products, inadequate know-how about good hygiene practices in the processing of milk and milk products. This results in higher wastage of milk and public health hazards, cultural 
indifferences to milk consumption (the traditional attitude that milk is for children, cats and the sick people), strong preference for local products, especially butter and ayib, which compete with selling the milk [4].

There is lack of private sector inputs, such as artificial insemination technicians, community animal health workers, business development service providers, animal feed suppliers, etc. for milk value chain actors, poorly developed dairy market infrastructure for collection and distribution of milk. This has limited accessibility (physical) to market/collection points, The milk value chain players are not actively working together, Milk collecting utensils and buckets used for up lifting the whole milk from the supply centers, where many smallholders are doing their sells, are not enough to collect and keep the quality of milk arriving to the collection centers of the processing plants. The milk collection centers are few in number, now well equipped, and limited in function to collection only rather that serving as center for diary education, services and innovation, Insufficient baseline data of the actors involved in processing.

The smallholder dairy farms barely employ appropriate and state of the art production technology to produce quality milk in demanded by processors and consumers [5]. Products Pasteurized Milk, Cheese, Butter, Yoghurt, Ghee, Cream and Ice Cream Status produced, and Milk Ice, Ice Confection, Flavored Milk ,Chocolate Milk, Fermented Skim Milk, Sterilized Milk, Milk Powder, imported Status of diversified dairy products production in Ethiopia Milk processing in the rural area used only traditional milking utensils for collecting or milking, storing and processing were observed. Due to technical and economic constraints, the major dairy products found in the rural area were yogurt-like fermented/sour milk (Ergo), traditional butter (Kibe), traditional ghee (Neter Kib ), and cottage cheese (Ayib) [6]. So, the objectives of this review are; to highlight the current status of milk processing; to know the opportunity of milk processing, and to review the challenges of milk processing in Ethiopia.

\section{Status of milk processing and milk production}

Milk processing: Milk processing is now in the hand of the private sector but is struggling against unfair competition from the informal sector and imported similar dairy commodities. The quality assurance system is weak and competition from imports is mainly based on quality difference rather than price. The collection points have the role of collecting the milk that will later be transported in the processing places, shortly after the milking. Practically, the milk should arrive at the processing places two hours after milking. Improvements in processing and quality assurance and efficiency are necessary for survival in increasingly liberalized, regional and global market [7].

This will require self-regulation rather than control from the government. This implies the industry will have to organize itself to better face challenges of the economic order of the region and global as whole. This is particularly true considering that raw and pasteurized milk are dominant milk products in and around Addis Ababa markets, powder milk is the third most consumed milk products [8]. The trend of processed dairy products (butter, ayib, and some cheese varieties) is increasing and there are only for milk processing units. Keeping in the view the recent trend, the investment in processing units of milk make a good investment sense. At present, the major sources of milk to Addis Ababa are the private farms around it, and the smallholder urban dairy within the city, using grade and cross-bred cows. The total milk production from these 5,170 dairy farms amounts to 34.95 million liters per annum Out of this $73 \%$ is sold, $10 \%$ is left for consumption at home, $9.4 \%$ goes to calves, and $7.6 \%$ is processed mainly into butter and ayib [9].

The other sources of milk to Addis Ababa are DDE Sholla (now LAME Dairy), Sebeta Agro Industry (Mama), LEMA Family Milk enterprises, Genesis Farm and recently Adaa Dairy Cooperative that collect milk from farmers as far away as 150 km radius. Products Pasteurized Milk, Cheese, Butter, Yoghurt, Ghee, Cream and Ice Cream Status produced, Milk Ice, Ice Confection, Flavored Milk, Chocolate Milk, Fermented Skim Milk, Sterilized Milk,Milk Powder Status is imported diversified dairy products production in Ethiopia Milk processing in the rural area used only traditional milking utensils for collecting or milking, storing and processing were observed. Due to technical and economic constraints, the major dairy products found in the rural area were yoghurt like fermented/sour milk (Ergo), traditional butter (Kibe), traditional ghee (Neter Kibe), and cottage cheese (Ayib) [6].

\section{Fresh milk}

The survey results showed that milk producers used different techniques to preserve fresh milk without clotting, such as smoking of the container and boiling of fresh milk, or refrigeration. In the rural area, smoking was the predominant practice performed by $100 \%$ of the households. About $13 \%$ of the households use the refrigerator, an option which was almost not present in the mixed crop-livestock and periurban areas. Cooling by putting the container with milk into a cold-water bath was practiced by about $4.8 \%$ of the periurban producers. It is obvious therefore, that for technical and economic reasons technologies in fluid milk processing such as steam pasteurization, sterilization and aseptic packing are not common on Ethiopian smallholder farms [4].

\section{Fermented/Sour Milk (Ergo)}

Ergo typically is semi-solid and in smallholder dairy farms it is produced from whole milk, while in milk cooperatives or other producer groups it is produced from skim milk. On average, milk is stored in a clay pot or a gourd over a period of 1 to 4 days and allowed to develop acidity. The mean shelf life of fermented milk was 3.8 days. According to the information collected from the respondents, fermented milk was the main product used as basis for further processing of various fermented milk products such as traditional butter, ghee, cottage cheese, butter milk and whey [6].

\section{Traditional butter (Kibe)}

In Ethiopian Traditional butter (kibe) is made from soured milk (ergo); cream is not used. The sour milk is placed in a clay 
churn or a bottle gourd. Churns are usually spherical, with a neck $10 \mathrm{~cm}$ in diameter at the narrowest point and a vent of 0.5 $\mathrm{cm}$ in diameter near the neck. The churn may have previously been smoked with Olea Africana besides imparting a distinct flavor to the butter; this practice has a bacteria static effect, and may reduce processing time by heating the churn. After filling, the churn stopper with a plug, a false banana leaf, or a piece of skin or leather stretched over the mouth and securely tied. The break point when butter starts to form can be detected by a change in the sound of the milk.

Many dairy women also insert a straw into the churn through the vent: if small butter grains are adhering to the surface of the straw, the break point has been reached. After churning for a few more minutes the straw is again inserted through the vent. If the straw is clean this indicates that the butter granules have coalesced into larger grains. The churn is then rotated on its base; the grains which collected in the center form lumps of butter which are skimmed off. The butter is then kneaded in cold water and washed to remove visible residual buttermilk. Butter is stored for about 10 days without spoilage. The farmer used local preservation method to protect the butter from spoilage. The main purposes of butter in the study area were for hair ointment, home consumption and for cash income by selling the butter. About $33.49 \%$ of the household use butter for cash income $32.53 \%$ for hair ointment and the remaining $33.97 \%$ use for home consumption [10].

\section{Cottage cheese (Ayib)}

Local cheese is one of the milk processing products. Cottage cheese is a soft curd-type cheese made by churning the buttermilk mainly at the household level, while in one farm and in milk cooperatives or other producer groups it was produced from skim milk. Cottage cheese was prepared by heating the buttermilk in an iron or clay pot until a curd-mass formed; followed by cooling to coagulate the curd. Then, the curd was separated from the whey through a fine meshed cloth or a sieve. ELFORA was the only cheese producing farm in the Dawa Chefa district. The farm produces cheese and butter in large quantity and sold this product in Addis Ababa. Generally, the farmer had no much tradition in producing and using cheese [10].

\section{Traditional ghee (Neter Kibe)}

Another milkprocessing product is ghee. Theingredients that are used to prepare ghee are Aswanseed (trachyspermumami) Rue (Rutagraveolence) Turmeric (curcumadomestica), Thyme (thymusserrulatus), garlic (Alliumsativum), Abish (Fenugreek), cardamom (Aframomumkoreri mao), ginger (Zingeberofficinale) and black cumin (Nigellasativa). Ghee is prepared from butter. The butter is heated over a low fire until all moisture had evaporated. When the non-fat solid turned to brown and frothing stops, preparation is stopped. According to the current study, the farmer store ghee from 6 month up to 7 years and used as a medicinal value.

Generally, to increase the shelf life of milk products, the current practice of further processing of traditional butter and cottage cheese into traditional ghee and Metata Ayib (ripened soft cheese) was typical for most smallholder dairy farmers of Ethiopia [11]. However, most of the milk processing was done by use of traditional household utensils under unsanitary conditions; to deliver a desirable flavor, plant materials were added to the finished product (traditional ghee and Metata Ayib ( ripened soft cheese) that might have contributed to the high microbial load. This is in agreement with the report of, Therefore, giving basic handling and health education for producers is likely to result in a better milk quality on the market, including shelf life and aspects of consumers' health [9]. In other hand, the technological processes of obtaining drinking milk are: transport and collection, cooling, milk normalization, homogenization, pasteurization, packing, storing steps and technologic scheme of modern milk processing ([7].

\section{Containers Used for processing of dairy products}

Containers used for milking and churning milk in the Rular, urban and peri-urban The majority of urban and peri-urban farms used plastic material, gourd and stainless steel for milking, where as in Rular areas used clay pot for churning milk. Some rural farmers used clay pot for churning milk and The milking material used in the Dangila zone western part of Amhara region were gourd, plastic material and stainless steel [9].

\section{Milk consumption in ethiopia}

Milk consumption in Ethiopia shows that most consumers prefer purchasing of raw milk because of its natural flavor (high-fat content), availability and lower price. Specific upper income market segments prefer and can afford packaged processed milk. Packaging costs alone may add up to $25 \%$ of the cost of processed milk depending on the type of packaging used. Polythene sachets of processed milk are cheaper alternatives. Ethiopians consume less dairy products than other African countries and far less than the world consumption. The present national average capita consumption of milk is $19 \mathrm{~kg} / \mathrm{year}$ as compared to $27 \mathrm{~kg}$ for other African countries and 100kg to the world per capita consumption [6]. The recommended per capita milk consumption is 200 liter/year.

On the other hand, they regularly consume other dairy products such as butter, ayib (cottage cheese) and fermented milk. $15.4 \%$ of the milk produced is sold in the market where as $54.7 \%$ milk produced is consumed at home. The remaining, $29.5 \%$ of the milk produced, is converted into butter and cottage cheese or ayib using traditional processing technologies [12]. It is to be expected that these proportions would start to change as collection infrastructures improve around the country.

There are differences in the demand for milk between rural and urban population. The demand for milk in rural areas is mainly for fresh whole milk and this demand is partially satisfied by home production and or purchased from neighboring producers. The demand for processed milk in the rural areas, is currently nil and expected not to change significantly shortly. The potential market for surplus milk which will have to be processed is found in the $7 \%$ urban population. The principal demand will continue to be fluid milk, much of which will be supplied through informal channels. In rural areas, consumption of milk and milk products is heavily 
influenced by livestock ownership, but in the urban areas, in particular, the principal determinant of consumption levels is income. The growth in demand resulted from a rapidly growing population, urbanization, change in lifestyle and consumption behaviors, and some increase in per capita incomes. In general, the milk market is characterized by low per capita consumption of milk which reduces [4].

\section{System of milk processing product marketing}

In Ethiopia, fresh milk, butter, fermented or soured whole milk (ergo), cottage cheese (ayib) and buttermilk (arera) are both formally and informally marketed. The informal milk marketing system is dominant, accounting for $95 \%$ of the milk marketed in the country. Producers directly sell their products to consumers or unlicensed traders or retailers through mutual price negotiation [13]. There is no license to operate and no checks on quality in the informal system [14]. The formal marketing system prevails in peri-urban and urban areas Milk is collected from producers by cooperatives and private collecting and processing plants, which channel the products to consumers, caterers, supermarkets and retailers $[15,13]$. Under the formal system, the quality of the milk is tested on delivery [14]. In some urban areas where milk collecting cooperatives or milk processing plants are absent, such as Bako and Nekemte towns of Oromia in western Ethiopia, the marketing system is informal [8]. In pastoral and agro-pastoral areas of eastern Ethiopia, milk from both cows and camels is sold in raw form through the informal marketing system [15]. In these areas, cow milk is processed to butter, and sale of soured milk and butter account for about $10 \%$ of the total milk market, while camel milk processing to other dairy products is less common. Besides raw milk, soured milk is also marketed in pastoralist areas like Borena in Oromia. Milk and other dairy products are generally marketed in towns and market places. Season and distance from the main towns affect the price, with the price being higher during dry season and closer to towns where demand is high $[8,6,13$,$] . Milk is transported from the local$ market places to the nearby towns by donkeys and light truck [15].

\section{Challenges of milk processing and dairy cattle produc- tion}

Insufficient raw Milk supply for Milk Processing Plants: This has forced the milk processing plants to operate with only $40 \%$ capacity and limited the production of pasteurized milk and other dairy products, Inadequate know-how concerning good hygiene practices in processing of milk and milk products [16]. This results in higher wastage of milk and public health hazards, cultural indifferences to milk consumption (a traditional attitude that milk is for children, cats and the sick local products, especially butter and ayib, which compete with selling the milk people, strong preference for, there is lack of private sector inputs, such as artificial insemination technicians, community animal health workers, business development service providers, animal feed suppliers, etc. contamination during milking and further handling coupled with storage time and temperature before consumption, deliberate adulteration of milk, substandard handling, transportation and distribution systems, inadequate fresh milk outlet and spoilage losses during milking for milk value chain actors, Poorly developed dairy market infrastructure for collection and distribution of milk [12]. This has limited accessibility (physical) to market/ collection points.

The milk value chain players are not actively working together. Milk collecting utensils and buckets used for up lifting the whole milk from the supply centers, where many smallholders are doing their sells, are not enough to collect and keep the quality of milk arriving to the collection centers of the processing plants. The milk collection centers are few, now well equipped, and limited in function to collection only rather that serving as center for diary education, services and innovation, Insufficient baseline data of the actors involved in processing. The smallholder dairy farms barely employ appropriate and state of the art production technology to produce quality milk in demanded by processors and consumers [5]. Shortage of feed, health problem, water scarcity and labor scarcity were major challenges which affect dairy cattle production and productivity and milk processing, feed was the first major constraints which accounted for a large proportion in dairy cattle production. From the fact points of view, quantitative and qualitative shortage of feed and fodder affects the performance of milking animals and milk processing, through underfeeding animals in general; in particular, it affects milk production negatively. The cause for shortage of feed may be because most farmers had small grazing land for animals; this was also true most natural pastures areas are converting to crop production.

Moreover, population numbers are becoming increase over time in turn; overgrazing was common due to inadequate use of natural pasture and crop residues and by-products; and lack of knowledge in improved forage (legumes, grasses, and crops-forage) in conserving and managing. As discussed with respondents, feed shortage of dairy cattle was the most serious problem during dry season in the study area this is because of most farmers are poorly experienced in hay and silage forage conservation however, the area has ample forage in summer season. The present review is in lined to [17] study of improved cattle in agro-pastoral systems of Central Tanzania who reported that the quantities and qualities of pasture is a big challenge for cattle production; in similar to current study [4]. Is also reported in North Gondar, Ethiopia who stated that shortage of feeds for dairy cattle production is major problem due to the shifting of natural pasture to cropland Improved Dairy production has been hampered by poor health and very high mortalities. According to the result of respondents, the second most important constraint was health problem and the most predominant dairy cattle killer diseases were mastitis (38.5\%), foot and mouth (33.3\%) and anthrax (28.1\%) diseases. the effect is more severe during summer and spring seasons because in those periods, the environment might be conducive for microbes and parasites reproduction [18] who reported that mastitis may developed if the quarter becomes intended as when the cow lies in mud or manure and bacteria intended the teat canals on the other hand [16] reported from Lake Zone in Tanzania foot mouth disease is most serious, followed by babesiosis and Lumpy skin disease. In similar way [19] study in Oyo area of Southwest Nigeria; foot and mouth disease 
and swollen join are major diseases for Adult ruminant while Diarrhea and foot and mouth diseases are major diseases for young ruminant. In similar manner also reported in Bench Maji Zone, Southwest Ethiopia; trypanosomosis, black leg, anthrax, bovine pasteurellosis, and gastro-intestinal parasites are major diseases in order of their importance challenges milk production and milk processing [20].

\section{The Opportunity of Milk processing and dairy cattle pro- duction}

The opportunities for milk processing in Ethiopia are: there is an increase in milk demand and to some extent consumption; possibilities/capacities for improvement are available; new product developments to increase customer selection (lifestyle products, probiotic yogurt, cottage cheese); distribution into multiple market channels to reach more consumers, institutional market segments (schools, hospitals), and improve packaging (e.g. out of home usage) [4]. There is political stability and conducive investment climate, government policy reforms, a market orientation that are favorable for dairy investment. The cost of production for livestock products is generally low in the country.

For milk production cost, Ethiopia is ranked among the countries with lowest cost of production in the world. The cost of labor is also low as compared to all the developed and many developing countries (personal communication), and the development the diary sector suitable condition to improve dairy production, productivity and milk processing for the future such as marketing accessibility, veterinary and artificial insemination service (AI) and infrastructure [21]. These were warranted to the dairy producers to remain with their dairy production activity.

The primary opportunity for the sector improvement followed by veterinary service and artificial insemination service and infrastructure respectively. The market opportunity is a key instrument for dairy industry because all dairy farm items are connected with a market channel, for example, to rent land for farm, purchase equipment for housing, labor and to sell milk and milk products, to purchase improved breeds, feeds, AI and drugs etc. About the marketing system, in the country land and labor are too cheap. There is also an increasing demand of milk and milk products consumption by the community. This may be related to population numbers are increasing from time to time in turn, feeding habits of the community are changing to animal origin.

Moreover, dairying provides the opportunity for smallholder farmers to use land, labor and feed resources and generate regular income. Expanding of veterinary and AI service, and infrastructure are also an important aspect for dairy industry development. Veterinary service accessibility is necessary to have health animal for production; as it enables to prevent, control and treat different diseases, and parasites which could be destructive for an animal as well as for human Nowadays, AI service is a crucial technology to disseminate improved breeds to smallholders in short time; AI service is also important to control transmissible diseases, it is also cost-effective. Infrastructure includes health center, training center, information, road etc. these can help to support different services such as adequate land access, organizing input supplies (improved breeds, feeds, AI, and drugs) and provision of credit, extension and training. More ever, as it was discussed with respondents and observed during data collection, government policy is good and encouraged for the dairy industry in the current situation and the area has a suitable climate (optimum rainfall and temperature) for dairy production improvement especially in midland and highland areas [22]. Ethiopia have other major opportunities of the dairy industry as rapid urbanization, substantial population growth and change in the living standard of the dwellers, the demand for milk and milk products in the areas are increasing [23]

\section{Conclusions}

The cost of production for livestock products is generally low in the Ethiopia. For milk production cost, Ethiopia is ranked among the countries with the lowest cost of production in the world. The cost of labor is also low as compared to all the developed and many developing countries(personal communication) products pasteurized milk, cheese, butter, yoghurt, ghee ,cream and ice cream status produced, milk Ice, ice confection, flavored milk, chocolate milk, fermented skim milk, Sterilized milk, milk Powder Status is imported diversified dairy products production in Ethiopia milk processing in the rural area used only traditional milking utensils for collecting or milking, storing and processing were observed. Due to technical and economic constraints, the major dairy products found in the rular area were yogurt like fermented/sour milk (Ergo), traditional butter (Kibe), traditional ghee (Neter Kibe), and cottage cheese (Ayib).

\section{Acknowledgements}

Authors deepest thanks goes to Debre Berhan University Staffs and the Communities for their logistic and material supports that highly aid for the completion of this work.

\section{References}

1. Duressa D, Kenea D, Keba W, Desta Z, Berki G, et al. (2014) Assessment of livestock production system and feed resources availability in three villages of Diga district Ethiopia ILRI: Addis Ababa, Ethiopia. Link: https://bit.ly/2yDRiCT

2. Sintayehu G, Samuel A, Derek B, Ayele S (2010) Diagnostic study of live cattle and beef production and marketing: Constraints and opportunities for enhancing the system ILRI and IFPRI, Addis Ababa, Ethiopia. Link: https://bit.ly/36CGkdk

3. CSA (2015) Agricultural Sample Survey Volume II report on livestock and livestock characteristics (private peasant holdings) Central Statistical Agency (CSA): Addis Ababa, Ethiopia. Link: https://bit.ly/36zLwPp

4. Gezu T, Haftu K, Sefa S (2015) Production, processing and constraints of cow milk in and around Hosanna Town, Hadya Zone, Southern Ethiopia. Wachemo University, P. O. Box 667, Hossana, Ethiopia. Link: https://bit.ly/2XGKbC6

5. SNV (2008) Netherlands Development Organization Study on Dairy Investment Opportunities in Ethiopia. Link: https://bit.ly/2AfNOSG

6. Abebe B, Zelalem Y, Ajebu N (2013) Handling, processing and utilization of milk and milk products in Ezha district of the Gurage zone, Southern Ethiopia. 5: 91-98. Link: https://bit.ly/2BaltTf 
7. Adelina F, Gheorghe B (2016) The Technological Procedure of Milk Processing. Transylvania University of Braşov, Braşov Romania. Link: https://bit.ly/36zLWoX

8. Geleti D, Hailemariam M, Mengistu A, Tolera A (2014) Analysis of fluid milk value chains at twoperi-urban sites in western Oromia, Ethiopia: Current status and suggestions on how they might evolve. Glob Vet 12: 104-120. Link: https://bit.ly/3gvCFmf

9. Bekele A, Fekadu B, Mitiku E (2015) Handling, processing and marketing of cow milk inurban and peri urban area of Dangila Town Western Amhara Region, Ethiopia. Glob J Food Sci Technol 3: 159-174.

10. Gebeyew K, Amakelew S, Eshetu M, Animut G (2016) Production, Processing and Handling of Cow Milk in Dawa Chefa District, Amhara Region, Ethiopia. J Veterinar Sci Technol 7: 286. Link: https://bit.ly/2M4P7vj

11. Ruegg $L$ (2006) Role of hygienic in efficient milking WCDS advances in Dairy Technology. Department of Dairy Science, University of Wisconsin 18: 285 293. Link: https://bit.ly/3ch4g7D

12. CSA (2010) Agricultural sample survey Report on livestock product utilization The Federal Democratic republic of Ethiopia Central Statistical Agency (CSA) Private Peasant Holdings Statistical Bulletin 468, Addis Ababa, Ethiopia.

13. Anteneh B, Tegegne A, Beyene F, Gebremedhin B (2010) Cattle milk and meat production and marketing systems and opportunities form market-orientation in Fogera woreda, Amhara region, Ethiopia Improving Productivy and Market Success (IPMS of Ethiopian Farmers Project, ILRI (aka ILCA and ILRAD). Addis Ababa, Ethiopia. Link: https://bit.ly/2zGvfvZ

14. Yilma Z, Guernebleich E, Sebsibe A, Fombad R (2011) A Review of the Ethiopian Dairy Sector FAO Sub Regional Office for Eastern Africa (FAO/SFE) Addis Ababa, Ethiopia.

15. Tegegne A, Gebremedhin B, Hoekstra D, Belay B, Mekasha Y (2013) Smallholde dairy production and marketing systems in Ethiopia: IPMS experiences and opportunities for market oriented development Working Paper No.31. ILRI: Addis, Ababa, Ethiopia. Link: https://bit.ly/2XbQILM

16. Laisser E, Chenyambuga S, Msalya G, Kipanyula M, Mdegela R, et al. (2015) Knowledge and perception on ticks, tick-borne diseases and indigenous cattle tolerance to East Coast fever in agro-pastoral communities of Lake Zone in Tanzania Livestock Research for Rural Development 27. Link: https://bit.ly/3dbowsj

17. Komwihangilo D, Mkonyi J, Masao D, Moto E, Mahiza A, et al. (2009) Performance and challenges in the management of improved cattle in agropastoral systems of Central Tanzania. 21. Link: https://bit.ly/2zD8FEs

18. Rosati A, Tewolde A, Mosconic S (2009) Animal production and animal science World wide WAP book of the year are view on developments and research in livestock system wage in gencadamic, Nezerland 24.

19. Daodu M, Babayemi O, lyayi E (2009) Herd composition and management practices of cattle production by pastoralists in Oyo area of Southwest Nigeria. Link: https://bit.ly/2M5ISZc

20. Weldegebriel DG (2015) Assessment of Production and Reproductive Performances of Cattle and Husbandry Practices in Bench-Maji Zone, Southwest Ethiopia. Global Journal of Animal Scientific Research 3: 441-452. Link: https://bit.ly/3eslbo4

21. Eyassu S, Reiner D (2014) Analysis of the dairy value chain: Challenges and opportunities for dairy development in Dire Dawa, Eastern Ethiopia Int J Agric Pol Res 2: 224-233. Link: https://bit.ly/3gvfQzi

22. Asrat A, Yilma Z, Nurfeta A (2013) Characterization of milk production systems in and around Boditti South Ethiopia. Livestock Research for Rural Development 25: 183. Link: https://bit.ly/3c9YTH1

23. Demissie B, Komicha H, Kedir A (2014) Factors affecting camel and cow milk marketed surplus: the case of eastern Ethiopia. Afr J Agric Sci Technol 2: 54 58
Discover a bigger Impact and Visibility of your article publication with Peertechz Publications

\section{Highlights}

* Signatory publisher of ORCID

- Signatory Publisher of DORA (San Francisco Declaration on Research Assessment)

* Articles archived in worlds' renowned service providers such as Portico, CNKI, AGRIS, TDNet, Base (Bielefeld University Library), CrossRef, Scilit, J-Gate etc.

* Journals indexed in ICMJE, SHERPA/ROMEO, Google Scholar etc.

* OAI-PMH (Open Archives Initiative Protocol for Metadata Harvesting)

* Dedicated Editorial Board for every journal

* Accurate and rapid peer-review process

* Increased citations of published articles through promotions

* Reduced timeline for article publication

Submit your articles and experience a new surge in publication services (https://www.peertechz.com/submission).

Peertechz journals wishes everlasting success in your every endeavours.

Copyright: () 2020 Getabalew M, et al. This is an open-access article distributed under the terms of the Creative Commons Attribution License, which permits unrestricted use, distribution, and reproduction in any medium, provided the original author and source are credited. 